\title{
Regression of solid breast tumours in mice by Newcastle disease virus is associated with production of apoptosis related- cytokines
}

\author{
Juraimi Raihan ${ }^{1,2+}$, Umar Ahmad ${ }^{3,4+}$ (D) , Yoke Keong Yong ${ }^{1 \dagger}$, Zolkapli Eshak ${ }^{5}$, Fauziah Othman ${ }^{1 *}$ and Aini Ideris ${ }^{6}$
}

\begin{abstract}
Background: Different strains of Newcastle disease virus (NDV) worldwide proved to have tumouricidal activity in several types of cancer cells. However, the possible anti-cancer activity of Malaysian NDV AF2240 strain and its mechanism of action remains unknown. The ability of cytokine-related apoptosis-inducing NDV AF2240 to treat breast cancer was investigated in the current study.

Methods: A total of 90 mice were used and divided into 15 groups, each group comprising of 6 mice. Tumour, body weight and mortality of the mice were determined throughout the experiment, to observe the effect of NDV and NDV + tamoxifen treatments on the mice. In addition, the toxic effect of the treatments was determined through liver function test. In order to elucidate the involvement of cytokine production induced by NDV, a total of six cytokines, i.e. IL-6, IFN- $\gamma$, MCP-1, IL-10, IL12p70 and TNF-a were measured using cytometric bead array assay (plasma) and enzyme-linked immunosorbent spot (isolated splenocytes).

Results: The results demonstrated that 4T1 breast cancer cells in allotransplanted mice treated with AF2240 showed a noticeable inhibition of tumour growth and induce apoptotic-related cytokines.

Conclusions: NDV AF2240 suppression of breast tumour growth is associated with induction of apoptotic-related cytokines. It would be important to further investigate the molecular mechanism underlaying cytokines production by Newcastle disease virus.
\end{abstract}

Keywords: Newcastle disease virus, AF2240, Breast cancer, 4T1 cells, Cytokines

\section{Background}

To date, cancer remains the tenth leading causes of death worldwide. According to National Cancer Registry Report 2007, breast cancer is the top ranking malignancy that affects Malaysians followed by colorectal cancer [1]. There are a total of 3292 new cases reported in the year 2007 and contributed $18.1 \%$ out of all the types of cancers in Malaysia [1]. However, the number of new cases are slightly less compared with the cases in 2003 (3738 cases reported) $[2,3]$ and the patient survival rate has

\footnotetext{
* Correspondence: fauziah@upm.edu.my

Juraimi Raihan, Umar Ahmad and Yoke Keong Yong equally contributed to this work.

${ }^{1}$ Department of Human Anatomy, Faculty of Medicine and Health Sciences, Universiti Putra Malaysia, UPM, 43400 Serdang, Selangor, Malaysia Full list of author information is available at the end of the article
}

also improved. This could be as a result of sensitization campaign, which increases awareness and educates citizen. In addition, early detection, development of advanced medical instruments and surgical techniques, and discovery of various new and effective anti-cancer agents may have resulted in the reduction in the number of cases.

There are various types of treatments available for breast cancer patients, including surgery, radiotherapy and chemotherapy. Also, numerous anti-cancer drugs, such as tamoxifen [4], trastuzumab [5] and bevacizumab [6], have been in the market since their discoveries. However, these drugs show many side effects. For instance, anastrozole that is used for the treatment of breast cancer patients after surgery leads to severe 
memory impairment [7] and long term use of tamoxifen increases the risk of endometrial cancer [8]. Due to this, tremendous efforts have been made by scientists around the world to explore and develop targeted drug systems with least or no side effects that will specifically target cancer cells without affecting normal healthy cells.

Recently, the trend of manipulating a virus to serve as an anti-cancer agent has been increasing $[9,10]$. Among all types of viruses, oncolytic virus specifically targets cancer cell without causing excessive damage to non-cancerous cells [11]. Numerous oncolytic viruses from different family exhibit different mechanism of tumour selectivity. For instance, herpes simplex virus mutant, G207 from herpesviridae family has been used for the treatment of malignant glioma [12]. Mumps virus from the family of paramyxoviridae has been previously used against ovarian cancer [13], and Sindbis virus from togaviridae family has been proposed as a therapy for cervical and ovarian cancers [14].

Apart from all these viruses, oncolytic Newcastle disease virus (NDV) also has potential as an anti-cancer agent because of its inability to induce immune escape mechanism in mammalian cells [15]. Thus, it may be suitable as an immunologic adjuvant in a human cancer vaccine [16]. NDV belongs to paramyxoviridae family, and causes inflammation of respiratory tract, brain and gastrointestinal tract to poultry [17]. However, it only causes mild flu-like symptoms and conjunctivitis in human [18]. While in mouse it is reported to stimulate production of type I interferon response upon infection and resistance of both normal and neoplastic cells to virus replication [19]. The most common strain that is found in Malaysia is NDV AF2440 [20]. It has been reported that NDV AF2240 was capable of stimulating apoptosis in breast cancer cells and the apoptotic effects were correlated with the production of pro-inflammatory cytokines in the tumour cells [21]. These effects are the first steps of immunotherapeutic effects of many crucial cytokines that help in combating breast tumour cells [22]. Several strains of NDV such as 73-T, HUJ, PV701 (MK107), MTH68, and Ulster have been shown to exhibit similar oncolytic properties as that of NDV AF2240 strain [23-25]. Furthermore, additional exploration of the three Malaysian oncolytic NDV strains, AF2240, F and V4, have also been studied on different types of cancer cell lines in both in vivo and in vitro screening [26-28]. Of all these strains, only AF2240 (velogenic) was found to be more effective and showed better cytotoxic effect on in vitro MCF-7 cells as compared to the V4-UPM (lentogenic) strain [29]. Thus, AF2240 strain has the most significant anti-cancer activity and had proven to be relatively effective in suppressing tumour growth through apoptosis induction [26, 30]. Given this, here, we investigated the possible apoptotic mechanism of NDV AF2240 against 4 T1 breast cancer cells through cytokines induction.

\section{Methods \\ Incubation of embryonated eggs}

Propagation of NDV virus was performed based on the method reported by Blaskovis and Styk [31]. Embryonated chicken eggs aged 9 to 10 days were obtained from Linggi Poultry Farm, Negeri Sembilan, Malaysia. Upon arrival, the eggs were sprayed with $70 \%$ ethanol and wiped thoroughly with tissue paper to prevent contamination. The eggs were then kept in a $37^{\circ} \mathrm{C}$-humidified incubator for $24 \mathrm{~h}$. The embryos were candled daily to monitor its viability. Same method was also used to determine the margin of air sac of the embryos, which were marked with a pencil prior to inoculation of the virus. All procedures were carried out under biological safety cabinet to minimize any contamination.

\section{Virus source and seed virus dilution}

The velogenic viscerotropic NDV strain AF2240 was isolated from a local outbreak in the late 1960s [32] and was obtained from Institute of Bioscience of the Universiti Putra Malaysia. Preparation of seed virus depends on the number of eggs used. Briefly, 10-fold of virus dilutions were prepared. First, three centrifuge tubes were filled with $9 \mathrm{ml}$ of phosphate buffer saline (PBS) and the subsequent tubes were filled with $27 \mathrm{ml}$ PBS. Approximately $1 \mathrm{ml}$ of virus was filtered using $0.45 \mu \mathrm{M}$ filter and added to the first centrifuge tube containing $9 \mathrm{ml}$ PBS and suspended for several times to get 1 in 10 dilutions of the virus. By using a syringe, approximately $1 \mathrm{ml}$ of the dilution was transferred to the second centrifuge tube before being suspended several times. This process was repeated until the third centrifuge tube. Finally, $3 \mathrm{ml}$ of dilution from the third centrifuge tube was transferred to the fourth centrifuge tube containing $27 \mathrm{ml}$ PBS to obtain a dilution of $10^{-4}$ NDV AF2240 which was used for the inoculation of virus in the embryonated chicken eggs.

\section{Virus inoculation}

Virus was inoculated in the eggs as per the method used by Alexander [33] with slight modification. A small hole approximately $1 \mathrm{~mm}$ in diameter was made using a sterile needle right above the air sac margin. By using a syringe, $0.1 \mathrm{ml}$ of virus dilution was inoculated into each egg. Then the eggs were sterilized using $70 \%$ ethanol before using melted candle or sterile tape to seal the hole. The eggs were then kept inside the incubator and checked for dead embryos using candling after $48 \mathrm{~h}$. The eggs, which found to have dead embryos were removed and kept in the refrigerator at $4{ }^{\circ} \mathrm{C}$. The eggs were monitored daily for $96 \mathrm{~h}$ or until $90 \%$ of the embryos died. All the eggs were kept in the refrigerator overnight to 
ensure that the blood vessel is constricted before virus harvesting process. This can avoid collection of blood during harvesting of the allantoic fluid.

\section{Virus harvesting}

The eggs were left under a biological safety cabinet at room temperature for $30 \mathrm{~min}$ to avoid excessive condensation on the shells once removed from the refrigerator. The eggs shells above the air sac were then removed and the membranes were punctured to collect the allantoic fluid. If there were any visible contamination, the eggs were immediately rejected. To confirm the presence of NDV in the allantoic fluid, a rapid test using chicken red blood cells was conducted. The allantoic fluids collected were kept in sterile tubes. Immediately after all the allantoic fluids were harvested, the clarification and purification of the virus was carried out.

\section{Virus clarification and purification}

In brief, the clarification of allantoic fluid was done at 6000 $\mathrm{g}, 4^{\circ} \mathrm{C}$ for $10 \mathrm{~min}$ by using a refrigerated centrifuge. The supernatants were then centrifuged at $20,000 \mathrm{rpm}, 4^{\circ} \mathrm{C}$ for 3 h. Again, the supernatant was discarded while the pellet was re-suspended and dissolved in $1 \mathrm{ml} \mathrm{NTE} \mathrm{buffer}(\mathrm{NaCl}$, Tris- $\mathrm{HCl}$, EDTA, pH 8.0). In addition, 30, 40, 50 and 60\% of sucrose gradients were prepared in ultra-clear tubes and kept overnight at $4{ }^{\circ} \mathrm{C}$. A few drops of virus in NTE buffer were added to the sucrose solution by using a sterile pipette until all the tubes were equally balanced. The tubes were then centrifuged at $38,000 \mathrm{rpm}, 4^{\circ} \mathrm{C}$ for $4 \mathrm{~h}$ by using pre-cooled SW41 rotor (Beckman Coulter, USA). After the centrifugation, observation and marking of the purified band of virus was made under inverted microscope. The band was collected and transferred into polyalomer tubes. The tubes were topped-up with NTE buffer and balanced before subjected to centrifugation at $20,000 \mathrm{rpm}$ at $4{ }^{\circ} \mathrm{C}$ for $2 \mathrm{~h}$. The pellets obtained were dissolved in $1 \mathrm{ml} \mathrm{NTE} \mathrm{buffer}$ and filtered using $0.4 \mu \mathrm{m}$ filter. Finally, the suspensions were kept at $-80^{\circ} \mathrm{C}$ until further use.

\section{Preparation of chicken red blood cells for virus titration}

Blood was withdrawn from the jugular vein of chicken by using syringe that filled with a mixture of PBS and EDTA to prevent the blood from clotting. The blood was transferred into $15 \mathrm{ml}$ tube and topped-up with PBS, then centrifuged at $1000 \mathrm{rpm}$ at room temperature for $10 \mathrm{~min}$. The supernatant was discarded and the red blood cells were re-suspended in PBS and centrifuged again. This process was repeated for 3 more times. For virus titration purpose, $50 \mu \mathrm{l}$ of the RBC was diluted in $100 \mathrm{ml}$ PBS to get $0.5 \%$ suspension of RBC cell in PBS.

\section{Haemagglutination (HA) test}

For HA test, 2nd to 24th well of 96-well plate were filled up with $50 \mu \mathrm{l}$ of PBS while the 1st well was filled up with $100 \mu \mathrm{l}$ of purified virus. $50 \mu \mathrm{l}$ of purified virus was transferred from the 1st well into the 2nd well to make a two-fold dilution and this continued until the 23rd well. Then, $50 \mu \mathrm{l}$ of the $0.5 \% \mathrm{RBC}$ suspension was added into all wells and left for $30 \mathrm{~min}$ at room temperature. The 1st well was served as positive control whereas the 24th well served as negative control. Any appearance of red button was observed in all wells except the 24th well that represented the virus HA titre.

\section{NDV titre for treatment}

Viruses were prepared from titre of $10^{8}\left(2^{8}\right)$ where it was neatly harvested from chicken eggs. Then the viruses were diluted to $8 \mathrm{HA}, 16 \mathrm{HA}, 32 \mathrm{HA}$ and $64 \mathrm{HA}$ unit of NDV as described in the Table 1 below.

\section{Cell culture}

Mouse mammary tumour cell line (4 T1) was obtained from the American Type Culture Collection (ATCC). Cell was cultured in RPMI-1640 medium that was supplemented with $10 \%$ fetal bovine serum and $1 \%$ penicillin/streptomycin. Cells were maintained at $37^{\circ} \mathrm{C}$ in a humidified atmosphere of $5 \% \mathrm{CO}_{2}$ in air. Culture medium was replaced every 2 to 3 days until the cell become $90 \%$ confluence before being subculture or used in the further experiment.

\section{Animals and xenograft mouse mammary tumour model} Healthy BALB/c mice weighing 15-20 g of age between 6 and 7 weeks old were obtained from Institute of Medical Research (IMR, Malaysia). The animals were reared in the animal house of Faculty of Medicine and Health Sciences, Universiti Putra Malaysia, where they were kept in a sterile plastic cage under hygienic conditions and were provided with food and water ad labium. Studies were conducted in Cancer Research Laboratory of Institute of Bioscience. All the animal works were conducted in accordance with institutional guidelines for Animal Care and Use Committee (ACUC), Faculty of Medicine and Health Sciences, Universiti Putra Malaysia. A concentration of $1 \times 10^{4}$ cells $/ \mathrm{ml}(0.1 \mathrm{cc}$ injection per mouse) was used to induced tumour in the

Table 1 Showed preparation of virus titres from $10^{8}$ to get 8 , 16, 32 and 64 HA units

\begin{tabular}{ll}
\hline Virus Titre & Dilution \\
\hline $8 \mathrm{HA}$ virus titre & 1 part of NDV $\left(10^{8}\right)$ or $100 \mathrm{ul}+900 \mu \mathrm{l} \mathrm{PBS}$ \\
$16 \mathrm{HA}$ virus titre & 1 part of NDV $\left(10^{8}\right)$ or $100 \mathrm{ul}+800 \mu \mathrm{l} \mathrm{PBS}$ \\
$32 \mathrm{HA}$ virus titre & 1 part of NDV $\left(10^{8}\right)$ or $100 \mathrm{ul}+700 \mu \mathrm{l} \mathrm{PBS}$ \\
$64 \mathrm{HA}$ virus titre & 1 part of NDV $\left(10^{8}\right)$ or $100 \mathrm{ul}+600 \mu \mathrm{l} \mathrm{PBS}$ \\
\hline
\end{tabular}


mice. The animals were not subjected to any form of suffering during the induction process. Subcutaneous (s.c.) injection of $4 \mathrm{~T} 1$ breast tumour cells was made into the mammary gland by gently penetrating the skin. All animals used in this experiment were humanely euthanized by $\mathrm{CO} 2$ asphyxiation upon meeting the criteria for tumour burden usually considered to be $\geq 150 \mathrm{~mm}^{3}$.

\section{Experimental design and NDV treatment}

Total 90 mice were used in this study and they divided into 15 groups (10 allotransplanted and 5 normal) with each group consisted of 6 mice. The normal category comprised of 5 groups of mice that were treated with 8 , 16, 32 and 64 HA NDV without xenotransplant of cancer cells (NDV), while, a group that is only treated with normal feeding (without NDV and cancer cells) was served as control (NC). On the other hand, another 10 groups were allotransplanted with $4 \mathrm{~T} 1$ breast cancer cells, which are under xenotransplantation category. Out of 10 groups, 4 groups were received $0.1 \mathrm{cc}$ of $0.5 \mu \mathrm{g} / \mathrm{ml}$ Tamoxifen in combination with $8,16,32$ and 64 HA of NDV, respectively $(\mathrm{CNDV}+\mathrm{T})$; another 4 groups were treated with 0.1 cc of $8,16,32$ and 64 HA of NDV only (CNDV), respectively. A group of allotransplanted mice without subjected to any virus or tamoxifen was served as cancer control (CC), while, another group was only treated with $0.1 \mathrm{cc}$ of $0.5 \mu \mathrm{g} / \mathrm{ml}$ tamoxifen was served as positive control (CT).

\section{Tumour, body weight and mortality}

The body weight and tumour weight of the mice were measured on the first and last day after inoculation with NDV and allotransplanted with $4 \mathrm{~T} 1$ breast cancer cells. The mortality rate of the mice for each group was also assessed every day until day 28 to determine the effect of NDV, NDV + Tamoxifen on the survival rate of the mice.

\section{Analysis of liver function}

For assessment of liver function, plasma enzyme activities of total bilirubin level, alanine aminotransferase (ALT) and aspartate aminotransferase (AST) were determined using an automated enzyme activity analyser (Beckman, USA).

\section{Cytokine determination by Cytometric Bead Array (CBA)} Measurement of interleukin-6 (IL-6) (Cat. No: 555240), interleukin-10 (IL-10) (Cat. No: 555252) interleukin-12p70 (IL-12p70) (Cat. No: 555256), interferon- $\gamma$ (IFN- $\gamma$ ) (Cat. No: 555138), monocyte chemoattractant protein-1 (MCP-1) (Cat. No: 555260), and tumour necrosis factor- $\alpha$ (TNF- $\alpha$ ) (Cat. No: 558874), were performed using a mouse inflammation cytometric bead array kits (CBA; BD Biosciences, Malaysia). The assay protocol was done strictly according to the manufacturer's instructions and the samples were analyzed with flow cytometer incorporated BD FACSComp ${ }^{\text {Tw }}$ software.

\section{Determination of cytokines by Enzyme-Linked} Immunosorbent Spot (ELISPOT)

Spleen cells suspension was prepared according to the method by Yang et al. [34] with slight modified. Spleen was removed and placed in plates containing Hank's balanced salt solution (HBSS) under sterile techniques. Spleen was then cut into small pieces and mashed through a nylon sieve. Clumps and debris were removed by allowing them to settle down before the cell suspension was transferred to clean centrifuge tube. Cell suspension was then centrifuged at $200 \mathrm{~g}, 4^{\circ} \mathrm{C}$ for $15 \mathrm{~min}$. Supernatant was discarded and cells were gently re-suspended with red cell lysing buffer in order to lyse erythrocytes. Again, the cell suspension was centrifuged at $200 \mathrm{~g}, 4^{\circ} \mathrm{C}$ for $5 \mathrm{~min}$ to remove cell debris and ghosts. After 2 washing in cold HBSS, the mononuclear cells were counted by trypan blue exclusion. Cell concentration was adjusted to the 1.5 to $3.0 \times 10^{5}$ cells $/ \mathrm{ml}$ in cell culture medium and kept on ice until further use. The ELISPOT assays were conducted by using the IL-6, IL-10, MCP-1, TNF- $\alpha$, IFN- $\gamma$ and IL-12p70 ELISPOT kit (BD Biosciences, Malaysia) according to the manufacturer's protocol. Samples were run in quadruplicates. The numbers of spots were enumerated manually by inspection under a dissecting microscope and automated ELISPOT plate reader.

\section{Statistical analysis}

Data are expressed as Mean \pm S.D. and analyses were done using Statistical Package for Social Sciences (SPSS version 22). Comparison between groups was determined by ANOVA and Dunnet test as post-hoc analysis was applied. $P<0.05$ was considered as significant.

\section{Results}

\section{Effect of NDV on body weight and tumour weight in} allotransplanted mice

All groups of mice showed significant increment in body weight compared with beginning stage (Table 2). On the other hand, the tumour in all groups increased in size, weight and no signs of regression at the end of the experiment except for groups CNDV8, 16, 32, 64, CNDV8 $+\mathrm{T}$ and CNDV16 + T (Table 2). The six groups mentioned above did not show any tumour growth at all. Thus, the percentage of inhibition was up to $100 \%$. In contrast, groups CNDV32 + T and CNDV64 + T did not show any signs of inhibition, and it seems there is an enhanced tumour growth. CT group which was treated Tamoxifen, a reference drug, showed slightly weak tumour suppression of about $16.55 \%$.

\section{Liver function test}

The activity of serum AST, ALT and the level of total bilirubin for all the treated groups are shown in Table 3. 
Table 2 Effect of velogenic viscerotropic (WNDV) AF2240 and tamoxifen in mortality rate, body and tumour weight of mice

\begin{tabular}{|c|c|c|c|c|c|c|c|}
\hline \multirow[t]{2}{*}{ Group } & \multicolumn{3}{|c|}{ Animal number } & \multicolumn{2}{|c|}{ Body weight \pm SD } & \multirow{2}{*}{$\begin{array}{l}\text { Tumour } \\
\text { weight (g) }\end{array}$} & \multirow{2}{*}{$\begin{array}{l}\text { Inhibition } \\
(\%)\end{array}$} \\
\hline & Beginning & End & Mortality rate (\%) & Beginning & End & & \\
\hline CC & 6 & 6 & 0 & $16.66 \pm 0.70$ & $21.26 \pm 1.24 *$ & $1.45 \pm 0.43$ & - \\
\hline$C T$ & 6 & 6 & 0 & $16.48 \pm 0.09$ & $20.88 \pm 0.79 *$ & $1.21 \pm 0.41$ & 16.55 \\
\hline \multicolumn{8}{|l|}{ CNDV } \\
\hline 8HA NDV & 6 & 6 & 0 & $16.77 \pm 0.11$ & $19.49 \pm 0.30$ * & NG ${ }^{\#}$ & 100 \\
\hline 16HA NDV & 6 & 6 & 0 & $16.64 \pm 0.32$ & $19.30 \pm 0.06 *$ & NG ${ }^{\#}$ & 100 \\
\hline $32 \mathrm{HA} \mathrm{NDV}$ & 6 & 6 & 0 & $16.86 \pm 0.10$ & $19.45 \pm 0.10 *$ & $N G^{\#}$ & 100 \\
\hline 64HA NDV & 6 & 6 & 0 & $16.54 \pm 0.31$ & $19.66 \pm 0.13 *$ & $N G^{\#}$ & 100 \\
\hline \multicolumn{8}{|l|}{$C N D V+T$} \\
\hline 8HA NDV & 6 & 6 & 0 & $16.93 \pm 0.41$ & $19.33 \pm 0.16 *$ & $N G^{\#}$ & 100 \\
\hline 16HA NDV & 6 & 6 & 0 & $16.86 \pm 0.14$ & $19.50 \pm 0.30 *$ & $N G^{\#}$ & 100 \\
\hline $32 \mathrm{HA} \mathrm{NDV}$ & 6 & 6 & 0 & $16.87 \pm 0.06$ & $21.00 \pm 0.40 *$ & $2.27 \pm 0.28^{\#}$ & -56.55 \\
\hline 64HA NDV & 6 & 6 & 0 & $16.66 \pm 0.06$ & $20.59 \pm 0.36 *$ & $3.64 \pm 0.23^{\#}$ & -151.03 \\
\hline
\end{tabular}

Results expressed in mean \pm S.D. ${ }^{*} p<0.05$ compared with beginning body weight; ${ }^{\#} p<0.05$ compared with cancer control (CC). CT, allotransplanted + tamoxifen; CNDV, allotransplanted + virus; CNDV+T, allotransplanted + virus + Tamoxifen; NG, negative

Table 3 Activities of ALT, AST and the level of total bilirubin in different groups of mice

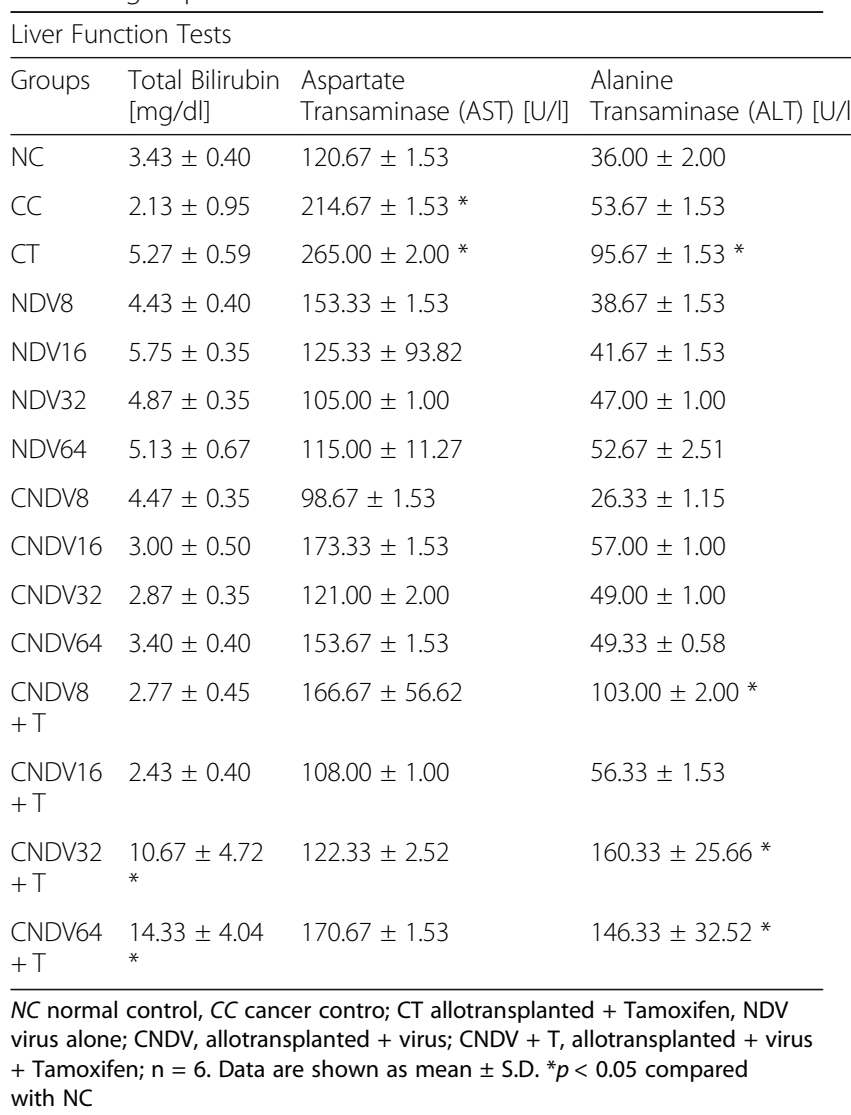

The level of total bilirubin for all groups, except for CNDV32 + T and CNDV 64 + T groups, showed no significant difference compared with the normal control group. Both treatments indicated a markedly elevated level of total bilirubin. In the case of enzyme activities, cancer control (CC), reference drug (CT), CNDV16 and CNDV64 + T significantly increased AST activity. This is especially apparent in the group treated with Tamoxifen (CT), which showed an increase one-fold higher than the normal control. On the other hand, groups $\mathrm{CT}$, CNDV8 + T, CNDV32 + T and CNDV64 + T showed a significant increment of ALT activity as compared to normal control.

\section{Cytokine analysis of the plasma/ serum by CBA assay}

Approximately one milliliter of plasma/serum from mice was collected following CA Argmann and J Auwerx [35] technique at week 1, 2, 3 and 4 from each group setting and cytokine concentrations were measured by CBA assay. A total of six different cytokines were determined, i.e. IL-6, IFN- $\gamma$, MCP-1, IL-10, IL-12p70 and TNF- $\alpha$. Among all the cytokines that were measured, the concentration of IL-6, MCP-1 and IL-12p70 in the group of cancer control (CC) were found to have a significant increase throughout the four weeks compared with normal control. In addition, $\mathrm{CC}$ group was found to produce the highest level of IL-6, MCP-1 and IL-12p70 (54.2 \pm 8.7 $\mathrm{pg} / \mathrm{ml}, 40.1 \pm 2.4 \mathrm{pg} / \mathrm{ml}, 11.2 \pm 2.9 \mathrm{pg} / \mathrm{ml}$ of, respectively), compared to normal control which are only $9.5 \pm 1.2 \mathrm{pg} /$ $\mathrm{ml}, \quad 4.1 \pm 0.1 \mathrm{pg} / \mathrm{ml}$ and $0.8 \pm 0.1 \mathrm{pg} / \mathrm{ml}$, respectively [Additional file 1: Table S1, Additional file 2: Table S2, Additional file 3: Table S3]. On the other hand, CC, CT, CNDV8, 16, 32 and 64 significantly produced IL-10 throughout the four weeks. However, production of 
IL-10 by group CNDV 16 ceased in week 3 and 4 [Additional file 4: Table S4]. There is no expression of IL-10 in the group NDV8-64. Apart from that, CC, CT, CNDV16 + T, CNDV32 + T and CNDV64 + T showed relatively high secretion of TNF- $\alpha$ throughout the experiment [Additional file 5: Table S5]. In the case of IFN- $\gamma$, all groups showed varying results in different week and consider relatively low production [Additional file 6: Table S6].

\section{Detection of spleen produced-cytokine by ELISPOT}

To determine the role of NDV virus induced - cytokines in suppressing $4 \mathrm{~T} 1$ breast cancer, mice splenocytes cytokine production was measured after inoculation with NDV virus throughout the experimental period. Cancer control group (CC) possessed relatively high secretion of IL-6, IFN- $\gamma$, MCP-1, IL-10, IL-12p70 and TNF- $\alpha$ from week 1 until week 4 compared with other groups [Figs. 1, 2, 3, 4, 5 and 6]. Groups that were treated with NDV virus alone did not show any significant difference compared with normal control $(\mathrm{NC})$ group in all the cytokine measurement. In the case of all the transplanted category, group treated with virus alone (CNDV) secreted relatively high level of cytokines when compared with the group treated with combination of virus and tamoxifen $(\mathrm{CNDV}+\mathrm{T})$. On the other hand, there was no cytokines observed in normal control group.

\section{Discussion}

Virotherapy has emerged as a novel and potential anticancer agent in recent years. Some viruses have oncolytic properties [36-39]. Due to its unique mechanism of action and its ability to impact on many types of human cancer, NDV has been proposed as a potent anti-cancer agent. Many strains of NDV were found to exhibit anti-cancer activity, for instance, $\mathrm{MTH}-68 / \mathrm{H}$ and AF2240 exhibited its anti-tumour effect via induction of nitric oxide synthesis from macrophages $[40,41]$. In addition, systemic therapy with NDV strain PV701 showed a promising result as an important therapy for patients with a solid tumour [42]. Apart from that, other strains of NDV that have been investigated are HUJ [43], 73-T [44], V4UPM [45] and AF2240 [46].

There are two strains of NDV that can be found commonly in Malaysia, namely AF2240 and V4-UPM. In our previous studies, exposure of NDV AF2240 showed an apoptotic effect against breast tumour cells [27, 47]. However, the underlying mechanism of action on how NDV AF2240 kills the breast cancer cells remains largely unclear. In order to understand the mechanism of action, the current study evaluated the serological effects of NDV AF2240 inoculation in enhancing breast tumour

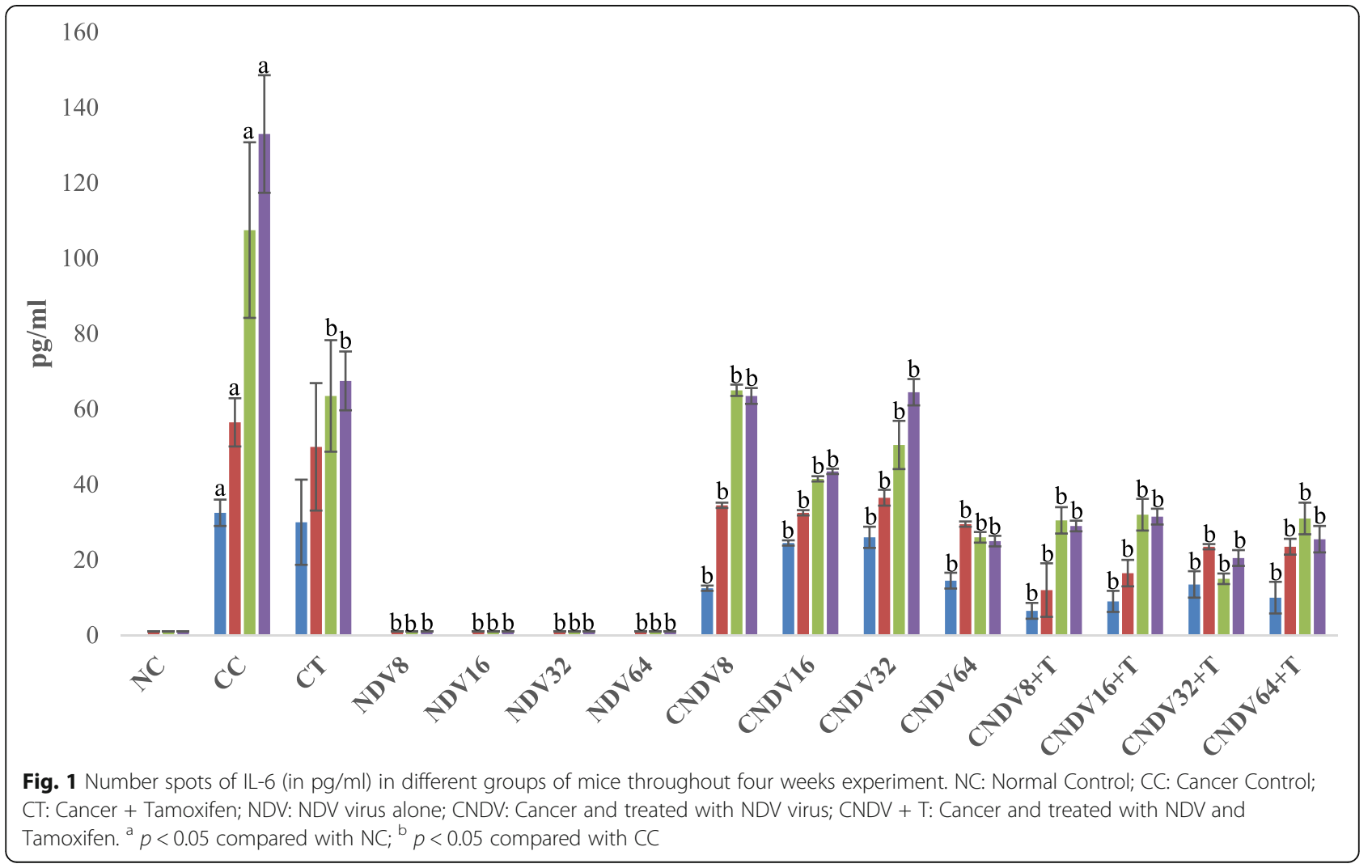




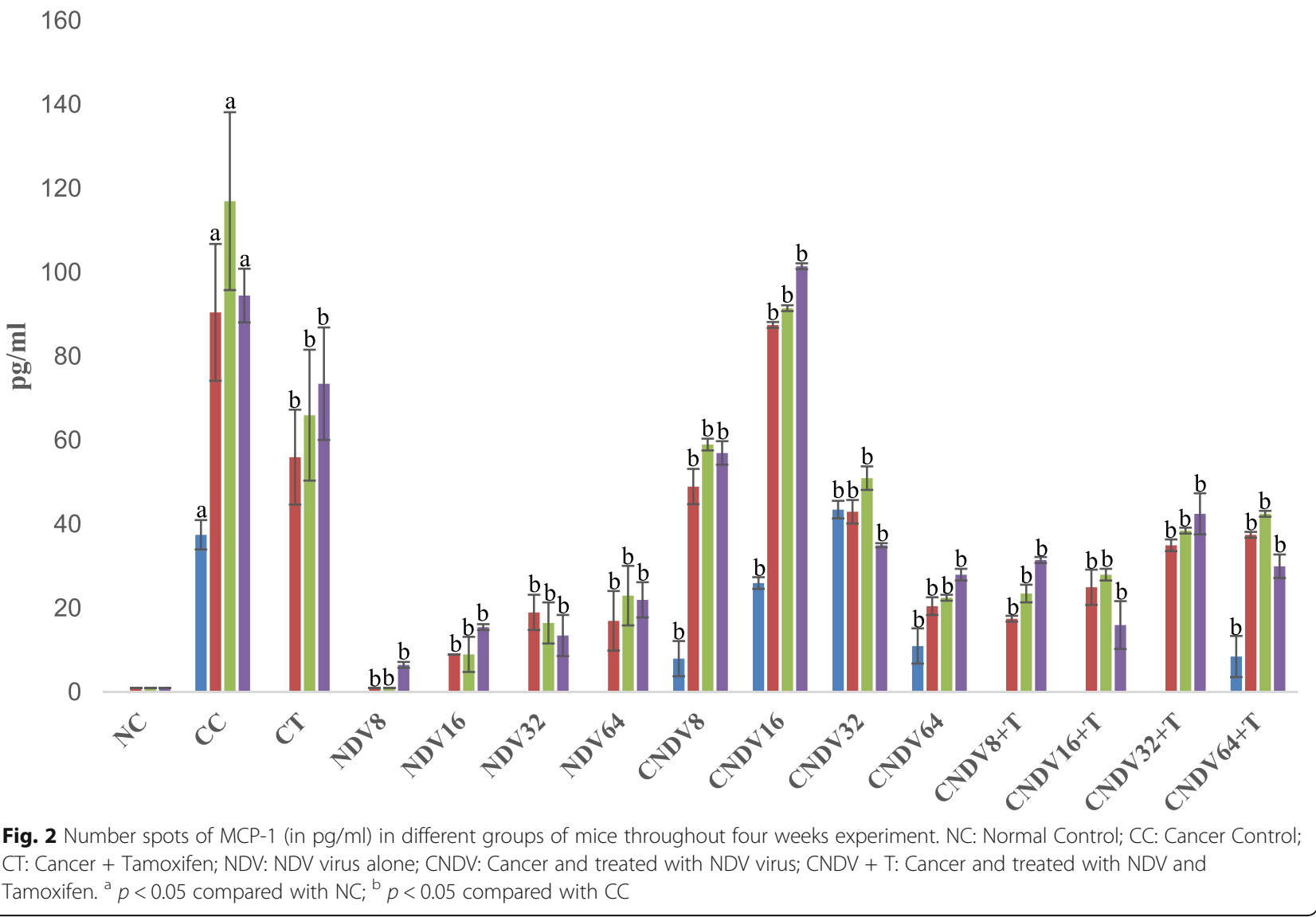

by inhibiting cytokines secretion by the host immune system. In addition, the effect of NDV AF2240 on the liver was evaluated using liver function test throughout.

Based on in vivo pilot study conducted prior to this experiment, the minimum effective dosage required to suppress tumour cell by NDV AF2240 was 8HA (data not shown). Therefore, the dosage that was used in the current study started from $8 \mathrm{HA}$ up to 64HA. Due to this, the effect of high concentration of NDV AF2240 on body weight and mortality rate were investigated throughout the experiment. Interestingly, the results of the present study indicated that the NDV AF2240 was tolerated in mice even at 64HA. In addition, there were no significant adverse physical changes observed in the body weight and food intake of mice in the treated groups as compared to control group. Several studies reported that pre- and post-operative cancer patients show weight loss or cachexia [48, 49]. However, the overall body weight increased over time in the present study. Thus, it is most likely that the increased in weight maybe due to the tumour itself. In the case of tumour growth profile, tumour growth in all transplanted $4 \mathrm{~T} 1$ breast cancer cells groups were completely inhibited due to treatment with NDV alone. Conversely, low concentration of NDV + Tamoxifen (8 and 16HA) completely suppressed tumour growth, while at high concentrations (32 and 64HA), enhanced tumour cell growth was observed. Therefore, it is believed that there may have been some antagonistic effect between high titre of NDV with tamoxifen, neither allowing NDV nor tamoxifen to execute its effect in killing 4 T1 tumour cells.

In order to evaluate the hepatotoxicity caused by the NDV as well as a combination of NDV and tamoxifen, liver biochemical parameters such as total bilirubin, AST and ALT were determined. Plasma concentrations of bilirubin, ALT and AST can be used as good indicators of the functionality and cellular integrity of the liver [50]. In addition, they are also good biomarkers that are used to predict any possible toxicity [51]. The present study demonstrated a significant elevation of bilirubin; AST and ALT in CNDV+T (32 and 64 HA) group compared to normal control. Moreover, the group treated with tamoxifen alone also showed significant increment in AST and ALT. This suggests that the high titre of NDV with tamoxifen or tamoxifen may cause damage to hepatocytes. Indeed, several studies revealed that tamoxifen might cause toxic hepatitis, cirrhosis and sub massive hepatic necrosis $[52,53]$. In terms of liver function enzymes, ALT is a more specific indicator of liver 


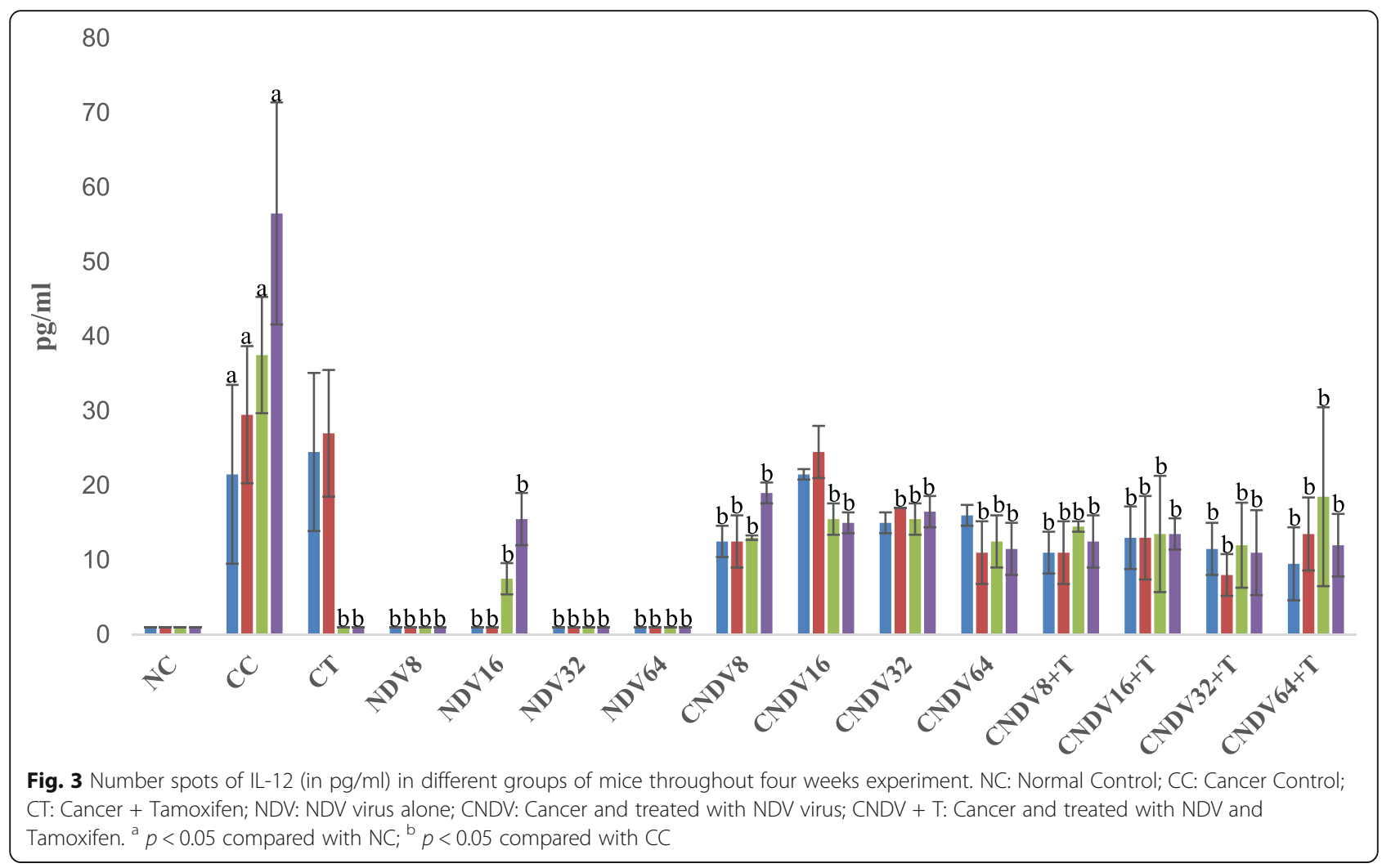

120

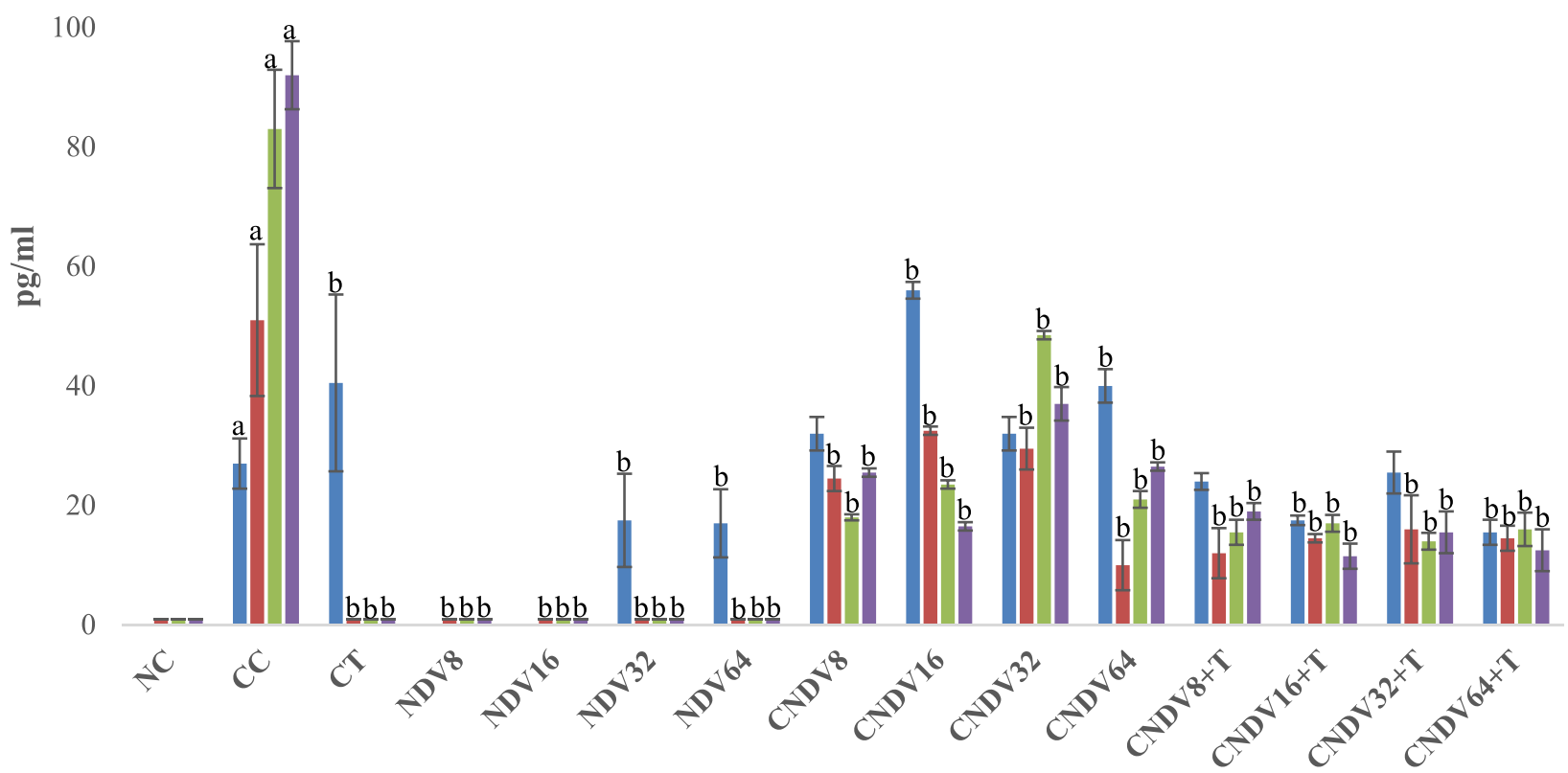

Fig. 4 Number spots of IL-10 (in pg/ml) in different groups of mice throughout four weeks experiment. NC: Normal Control; CC: Cancer Control; CT: Cancer + Tamoxifen; NDV: NDV virus alone; CNDV: Cancer and treated with NDV virus; CNDV + T: Cancer and treated with NDV and Tamoxifen. ${ }^{a} p<0.05$ compared with $\mathrm{NC}_{i}{ }^{\mathrm{b}} p<0.05$ compared with CC 

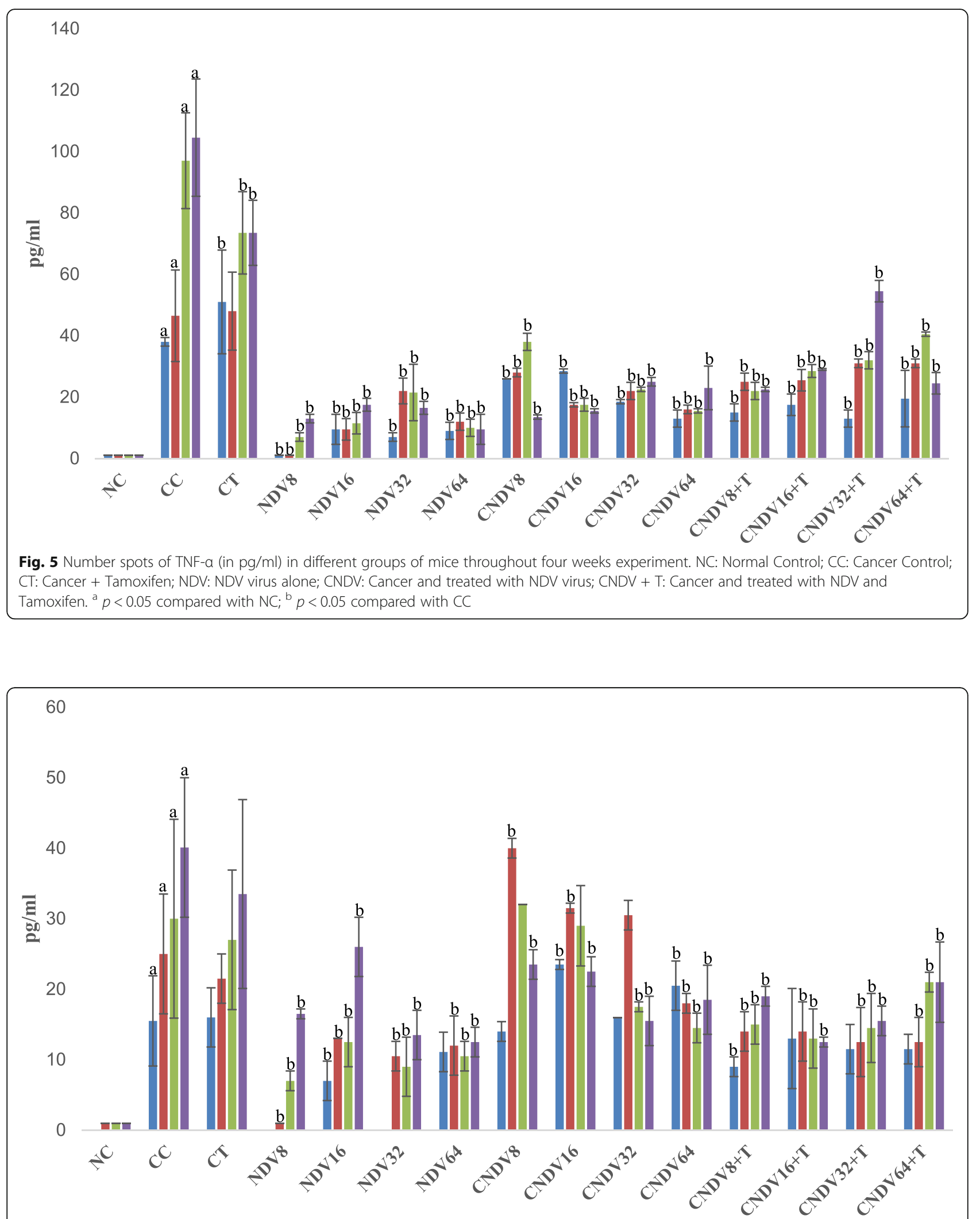

Fig. 6 Number spots of IFN- $\gamma$ (in pg/ml) in different groups of mice throughout four weeks experiment. NC: Normal Control; CC: Cancer Control; CT: Cancer + Tamoxifen; NDV: NDV virus alone; CNDV: Cancer and treated with NDV virus; CNDV + T: Cancer and treated with NDV and Tamoxifen. ${ }^{\mathrm{a}} \mathrm{p}<0.05$ compared with $\mathrm{NC} ;{ }^{\mathrm{b}} \mathrm{p}<0.05$ compared with CC 
function, as compared to AST, which can also be found in red blood cells, cardiac and skeletal muscle [54]. Increased level of bilirubin may also indicate liver disease, biliary structure, cardiac problem and neonatal hyperbilirubinaemia [55]. Therefore, careful consideration in interpreting the bilirubin level, ALT and AST enzyme activity has to be made with regards to findings from this study. Moreover, many factors can contribute to the elevation of the parameters observed here.

The current study showed that inoculation of NDV AF2240 could be beneficial for the treatment of breast cancer, but little is known about its mechanism of action. In order to elucidate a possible mechanism for the anti-neoplastic activity of NDV, immunological effects induced by NDV AF2240 was evaluated by determining the following cytokines; IL-6, IL-10, IL-12p70, IFN- $\gamma$, TNF- $\alpha$ and MCP-1. All the cytokines were measured by using ELISPOT and cytometric bead array assay. Many cytokines are known to be involved in inhibiting or enhancing tumour growth. For instance, IL-6, an inflammatory cytokine, is known to mediate many undesired, detrimental effects that contribute to cardiovascular disease [56], bowel disease [57] and Alzheimer disease [58]. In addition, IL-6 was found to pathologically regulate various types of cancer, including colorectal cancer [59], lung cancer [60] and breast cancer [61]. Recent studies reported that up-regulation of IL-6 level leads to cancer cells resistance to chemotherapeutic drugs [62]. It seems capable of protecting cells from damage by free radicals and this effect extends to the cells that might have escaped from normal cell cycle pathway [63]. Interestingly, findings reported here showed a significant suppression of IL- 6 in the breast cancer-bearing mice challenged with NDV (8-64HA) and a combination of NDV and tamoxifen (8-64HA) compared with cancer control group (CC). Hence, NDV suppressed tumour growth may be through the impairment of IL-6 secretion.

As TNF- $\alpha$ is considered as a potential candidate for virotherapy in cancer patients, we have further analyzed the expression level for TNF- $\alpha$ in NDV treated $4 \mathrm{~T} 1$ breast cancer model. There are two mechanisms proposed for the antineoplastic activity of NDV: TNF- $\alpha$ secretion by activated peripheral blood mononuclear cells and enhancement in sensitivity of neoplastic cells towards TNF- $\alpha[64,65]$. In addition, recent studies also demonstrated that NDV induced apoptosis process mediated by TNF [66]. A part from that, it is also shown to enhance vascular permeability, facilitating the uptake and accumulation of chemotherapeutic drugs [67]. Hence, TNF- $\alpha$ therapy is a promising antineoplastic treatment. Present results revealed a marked increase of TNF- $\alpha$ concentration in $4 \mathrm{~T} 1$ breast cancer bearing mice challenged with a combination of NDV AF2240 and tamoxifen. Although the result for cancer control is higher in CBA assay compared with ELISPOT, this may be that the cytokine-producing cell measurements done by using ELISPOT did not account for productivity per individual cells. Thus, it does not allow the differentiation on whether few cells produce many cytokines or many cells produce little cytokines as shown by CBA assay.

IL-12 is capable of evoking a potent immune response and also down-regulates the formation of new blood vessels into growing tumour [68]. IFN- $\gamma$ is known as the key downstream factor induced by IL-12. Thus, the antitumour activity exerted by IL-12 is believed largely to be due to the local IFN- $\gamma$ production and subsequent activation of the angiostatic chemokines IP-10 [69]. Nastala and her colleagues [70] reported that the tumour regression induced by recombinant IL-12 is associated with the production of IFN- $\gamma$. Hence, IL-12 therapy is crucial for cell-mediated-antitumour activity. However, results from this study revealed that treatment with NDV or $\mathrm{NDV}+$ tamoxifen induces sustained low concentration of IL-12 and IFN- $\gamma$ in breast cancer-bearing mice. This finding could suggest that NDV induces tumour regression via other signaling molecules or cytokines, but not IL-12 - IFN- $\gamma$ pathway.

IL-10 is known to play an important role in inflammation. It suppresses the activation of macrophages and dendritic cells. In addition, it also inhibits numerous innate immune response and is associated with inflammatory activities [71]. On the other hand, high secretion of IL-10 has been found in various types of cancer cell, including breast, kidney, colon, lung and pancreas cancer [72-75]. In the context of breast cancer, IL-10 may act as a two-edged sword. Elevation of IL-10 level could facilitate the development of cancer by supporting tumour cell escape from host immune response via activation of PRL-R variants with altered pro-inflammatory or abrogated function. On the other hand, IL-10 could also prevent or reduce tumour growth and metastasis via suppression of angiogenesis [76]. Current results showed that cancer control (CC) group expressed a high level of IL-10, and this is similar to the studies done by Kozlowski et al. [77] and Razmkhah et al. [78]. Interestingly, breast cancer-bearing mice treated with a combination of NDV and tamoxifen showed a reduction in IL-10. Hence, it could be suggested that NDV + tamoxifen exhibited a synergistic effect, which prevents cancer growth through suppression of IL-10 secretion.

Lastly, the role of monocytes chemotactic protein-1 (MCP-1) was also evaluated in the current study. Several studies documented that upregulation of MCP-1 could assist in tumour growth by neovascularization [79, 80]. In addition, a clinical study done by Lebrecht et al. [81] reported that elevation of the MCP-1 level correlated with advanced tumour stage and lymph node involvement in patients with breast cancer. Current data 
showed that there is only slight reduction of MCP-1 level in cancer bearing-mice treated with NDV alone or combination of NDV and tamoxifen compared to CC group. High concentration of MCP-1 found in CC could be due to release by cancer cells or inflammation [82]. Thus, NDV induced tumour regression may not be through suppression of MCP-1 pathway.

\section{Conclusions}

Based on the findings mentioned above, our data support that NDV AF2240 could potentially serve as an alternative treatment for breast cancer therapy. The dose or titre for virus needs proper research and study for its efficacy and safety use. A part from that, NDV AF2240 induced tumour regression may act through up-regulation or down-regulation of different cytokines. However, further experimental studies need to be carry out in vitro and in vivo to decipher the molecular mechanism underlaying tumour cytolysis and cytokines released due to NDV infection.

\section{Additional files}

Additional file 1: Table S1. Concentration of IL-6 in both the NDV treated and control groups expressed in $\mathrm{pg} / \mathrm{ml}$ throughout week 1 to week 4. (DOCX $15 \mathrm{~kb}$ )

Additional file 2: Table S2. Concentration of IFN- $y$ in both the NDV treated and control groups expressed in $\mathrm{pg} / \mathrm{ml}$ throughout week 1 to week 4. (DOCX $15 \mathrm{~kb}$ )

Additional file 3: Table S3. Concentration of MCP-1 in both the NDV treated and control groups expressed in $\mathrm{pg} / \mathrm{ml}$ throughout week 1 to week 4. (DOCX $15 \mathrm{~kb}$ )

Additional file 4: Table S4. Concentration of IL-10 in both the NDV treated and control groups expressed in $\mathrm{pg} / \mathrm{ml}$ throughout week 1 to week 4. (DOCX $15 \mathrm{~kb}$ )

Additional file 5: Table S5. Concentration of IL-12p70 in both the NDV treated and control groups expressed in $\mathrm{pg} / \mathrm{ml}$ throughout week 1 to week 4. (DOCX $15 \mathrm{~kb}$ )

Additional file 6: Table S6. Concentration of TNF-a in both the NDV treated and control groups expressed in $\mathrm{pg} / \mathrm{ml}$ throughout week 1 to week 4. (DOCX $15 \mathrm{~kb})$

\section{Abbreviations}

CC: Cancer Control; CNDV + T: Cancer and treated with NDV and Tamoxifen; CNDV: Cancer and treated with NDV virus; CT: Cancer + Tamoxifen; IFNY: Interferon gamma; IL-10: Interleukin 10; IL12p70: Interleukin 12; IL6: Interleukin 6; MCP-1: Monocyte chemoattractant protein-1; NC: Normal Control; NDV: Newcastle disease virus; NG: Negative; TNF-a: Tumour necrosis factor alpha; WNDV: Velogenic Viscerotropic

\section{Acknowledgments}

Equipment was used in conducting some of the assays done in this study and most of which are from Cancer Research Laboratory and Immunotherapeutic Laboratory of the Institute of Bioscience, and Laboratory Animal House of the Faculty of Medicine and Health Sciences. Virus propagation and purification were carried out in Biologic Laboratory of the Faculty of Veterinary Medicine, Universiti Putra Malaysia (UPM). We thank Dr. Mahmoud Bukar Maina of the University Sussex, UK for manuscript editing and constructive criticism.

\section{Funding}

This work was supported by the Cancer Research Fund of Malaysia and GPIPS University Research Grant provided to Prof. Dr. Fauziah Othman by National Cancer Council (MAKNA) and Universiti Putra Malaysia (UPM) respectively. Funding bodies did not have any influence in the design of the study and data collection, analysis and interpretation of data or in writing the manuscript

\section{Availability of data and materials}

All data generated or analyzed during this study are included in this published article and its Additional files.

\section{Author's Contributions}

$F O, J R, U A, Z E, A R$ and Al participated in the design of the research. JR carried out the experiments and analysed the data with the help from UA and ZE. YYK and UA analysed the data and wrote the paper. FO provided funding and supervised the study. All authors read and approved the final manuscript.

\section{Ethics approval and consent to participate}

This study was conducted in accordance with the recommendations from the guidelines provided by the Institutional Animal Care and Use Committee (IACUC) of the Faculty of Medicine and Health Sciences (FMHS), Universiti Putra Malaysia (UPM). The protocol was approved and monitored by the Ethics Research Committee of the Universiti Putra Malaysia.

\section{Consent for publication}

Not applicable.

\section{Competing interest}

The authors declare that they have no competing interests.

\section{Publisher's Note}

Springer Nature remains neutral with regard to jurisdictional claims in published maps and institutional affiliations.

\section{Author details}

'Department of Human Anatomy, Faculty of Medicine and Health Sciences, Universiti Putra Malaysia, UPM, 43400 Serdang, Selangor, Malaysia. ${ }^{2}$ Ministry of Health Malaysia, 62590 Putrajaya, Malaysia. ${ }^{3}$ Medical Genetics Laboratory, Genetics and Regenerative Medicine Research Centre, Faculty of Medicine and Health Sciences, University Putra Malaysia, 43400 Serdang, Selangor, Malaysia. ${ }^{4}$ Genetics and Cytogenetics Unit, Department of Anatomy, Faculty of Medicine, Bauchi State University, Gadau, PMB 65, Itas/Gadau, Nigeria.

${ }^{5}$ Faculty of Pharmacy, Universiti Teknologi Mara, 42300 Bandar Puncak Alam, Selangor, Malaysia. ${ }^{6}$ Faculty of Veterinary Medicine, Universiti Putra Malaysia, 43400 Serdang, Selangor, Malaysia.

Received: 1 December 2017 Accepted: 25 March 2019

Published online: 04 April 2019

\section{References}

1. Omar ZA, NSI T. National Cancer Registry Report 2007. In: Malaysia Cancer Statistics-Data and Figure. Kuala Lumpur: National Cancer Registry, Ministry of Health Malaysia; 2011. p. 89.

2. Azizah AM, Nor Saleha IT, Noor Hashima A, Asmah ZA, Mastulu W. Malaysian National Cancer Registry Report 2007-2011. Malaysia Cancer Statistics Data and Figure 2007. Malaysia cancer statistics, data and figure. Putrajaya: National Cancer Institute, Ministry of Health; 2016

3. Yip CH, Taib NA, Mohamed I. Epidemiology of breast cancer in Malaysia. Asian Pac J Cancer Prev. 2006;7(3):369-74.

4. Jordon V. Fourteenth Gaddum Memorial Lecture. A current view of tamoxifen for the treatment and prevention of breast cancer. $\mathrm{Br} J$ Pharmacol. 1993;110(2):507-17.

5. Goldenberg MM. Trastuzumab, a recombinant DNA-derived humanized monoclonal antibody, a novel agent for the treatment of metastatic breast cancer. Clin Ther. 1999;21(2):309-18.

6. Rugo HS. Bevacizumab in the treatment of breast cancer: rationale and current data. Oncologist. 2004;9:43-9.

7. Bender CMSS, Brufsky AM, Ryan CM, Vogel VG, Rastogi P, Cohen SM, Casillo FE, Berga SL. Memory impairments with adjuvant anastrozole versus 
tamoxifen in women with early-stage breast cancer. Menopause. 2007;14(6): 995-8.

8. Grilli S. Tamoxifen (TAM): the dispute goes on. Ann 1st Super Sanita. 2006; 42(2):170-3.

9. Stojdl DFLB, Knowles S, Marius R, Atkins H, Sonenberg N, Bell JC. Exploiting tumor-specific defects in the interferon pathway with a previously unknown oncolytic virus. Nat Med. 2000;6(7):821-5.

10. Heise CHT, Johnson L, Brooks G, Sampson-Johannes A, Williams A, Hawkins L, Kirn D. An adenovirus E1A mutant that demonstrates potent and selective systemic anti-tumoral efficacy. Nat Med. 2000;6(10):1134-9.

11. Parato KASD, Forsyth PA, Bell JC. Recent progress in the battle between oncolytic viruses and tumours. Nat Rev Cancer. 2005;5(12):965-76.

12. Markert JMMM, Rabkin SD, Gillespie GY, Todo T, Hunter WD, Palmer CA, Feigenbaum F, Tornatore C, Tufaro F, Martuza RL. Conditionally replicating herpes simplex virus mutant, G207 for the treatment of malignant glioma: results of a phase I trial. Gene Ther. 2000;7(10):867-74.

13. Myers RGS, Harvey M, Soeffker D, Frenzke M, Abraham K, Shaw A, Rozenblatt S, Federspiel MJ, Russell SJ, Peng KW. Oncolytic activities of approved mumps and measles vaccines for therapy of ovarian cancer Cancer Gene Ther. 2005;12(7):593-9.

14. Unno YSY, Kondo F, lgarashi N, Wang G, Shimura R, Yamaguchi T, Asano T, Saisho H, Sekiya S, Shirasawa H. Oncolytic viral therapy for cervical and ovarian cancer cells by Sindbis virus AR339 strain. Clin Cancer Res. 2005;11(12):4553-60.

15. Zamarin D, Palese P. Oncolytic Newcastle Disease Virus for. Cancer Therapy. 2012:25-30.

16. Washburn B, Schirrmacher V. Human tumor cell infection by Newcastle Disease Virus leads to upregulation of HLA and cell adhesion molecules and to induction of interferons, chemokines and finally apoptosis. Int J Oncol. 2002;21(1):85-93.

17. Alexander DJ SD: Newcastle disease, other avian paramyxoviruses and pneumovirus infection. In: Disease of Poultry. 12 edn. Edited by YM S: Ames: lowa State University Press; 2008: 75-100.

18. Park MS, García-Sastre A, Cros JF, Basler CF, Palese P. Newcastle disease virus $\checkmark$ protein is a determinant of host range restriction. J Virol. 2003;77(17): 9522-32.

19. Elankumaran S, Chavan V, Qiao D, Shobana R, Moorkanat G, Biswas M, Samal SK. Type I interferon-sensitive recombinant Newcastle disease virus for oncolytic virotherapy. J Virol. 2010;84(8):3835-44.

20. Meyyappan N. Effect Of Newcastle Disease Virus On The Mcf-7 And MdaMb-231 Breast Cancer Cell Lines Universiti Putra Malaysia; 2003.

21. Fauziah OOA, Patimah I, Aini I. Microscopic evaluation of Newcastle disease virus (NDV) a killer in chicken but a possible live saver in human. J Elect Micro Soc Thailand. 2002;16:272.

22. Coughlin CMSK, Wysocka M, Aruga E, Kurzawa H, Chang AE, Hunter CA, Fox JC, Trinchieri G, Lee WM. Interleukin-12 and interleukin-18 synergistically induce murine tumor regression which involves inhibition of angiogenesis. J Clin Invest. 1998;101(6):1441-52.

23. Yurchenko KS, Zhou P, Kovner AV, Zavjalov EL, Shestopalova LV, Shestopalov AM. Oncolytic effect of wild-type Newcastle disease virus isolates in cancer cell lines in vitro and in vivo on xenograft model. PLoS One. 2018;13(4):e0195425.

24. Yaacov B, Eliahoo E, Elihaoo E, Lazar I, Ben-Shlomo M, Greenbaum I, Panet A, Zakay-Rones Z. Selective oncolytic effect of an attenuated Newcastle disease virus (NDV-HUJ) in lung tumors. Cancer Gene Ther. 2008;15(12):795-807.

25. Mazija H, Cajavec S, Ergotic N, Ciglar-Grozdanic I, Gottstein Z, Ragland WL. Immunogenicity and safety of Queensland V4 and Ulster $2 \mathrm{C}$ strains of Newcastle disease virus given to maternally immune, newly hatched chickens by nebulization. Avian Dis. 2010;54(1):99-103.

26. Alabsi AM, Ali R, Ideris A, Omar AR, Bejo MH, Yusoff K, Ali AM. Anti-leukemic activity of Newcastle disease virus strains AF2240 and V4-UPM in murine myelomonocytic leukemia in vivo. Leuk Res. 2012;36(5):634-45.

27. Othman FAIGMEAR. Oncolytic effect of Newcastle disease virus AF2240 strain on the MCF-7 breast cancer cell line. Yakhteh Med J. 2010;12:17-24.

28. Zamarin D, Palese P: Oncolytic Newcastle Disease Virus for Cancer Therapy Mechanisms of NDV-mediated Oncolysis. 2013, 7(3):347-367.

29. Meyyapan N: Oncolytic Effect of Newcasle Disease Virus on te MCF-7 and MDA-MB-231 Breast Cancer Cell Lines. Master. Universiti Putra Library: Universiti Putra Malaysia; 2003.

30. Anushia S: Effect of Newcastle Disease Virus AF2240 on Allografted 4T1 Breast Cancer Cells in BALB/C Mice. Master. Universiti Putra Library: Universiti Putra Malaysia; 2010
31. Blaskovic DSB. Laboratory methods of virus transmission in multicellular organisms. Virology. 1967;1:163-233.

32. Yusoff K, Tan WS. Newcastle disease virus: macromolecules and opportunities. Avian Pathol. 2001;30(5):439-55.

33. DJ Alexander: Newcastle disease diagnosis. In: Newcastle Disease. edn. Edited by DJ A. Boston, Dordrecht, London: Kluwer Academic Publishers; 1998: $147-160$.

34. Yang $\mathrm{R}$, Pei X, Wang J, Zhang Z, Zhao H, Li Q, Zhao M, Li Y. Protective effect of a marine oligopeptide preparation from chum salmon (Oncorhynchus keta) on radiation-induced immune suppression in mice. J Sci Food Agric. 2010;90(13):2241-8.

35. Argmann CA, Auwerx J: Collection of blood and plasma from the mouse. Curr Protoc Mol Biol 2006, Chapter 29:Unit 29A 23.

36. Abschuetz A, Kehl T, Geibig R: Oncolytic murine autonomous parvovirus, a candidate vector for glioma gene therapy, is innocuous to normal and immunocompetent mouse glial cells. Cell and tissue ... 2006.

37. Angelova AL, Aprahamian M, Balboni G, Delecluse $\mathrm{H}-J$, Feederle R, Kiprianova I, Grekova SP, Galabov AS, Witzens-harig M, Ho AD, et al. Oncolytic Rat Parvovirus H-1PV, a Candidate for the Treatment of Human Lymphoma : In Vitro and In Vivo Studies. Nature. 2009;17(7):1164-72.

38. Bartlett DL, Liu Z, Sathaiah M, Ravindranathan R, Guo Z, He Y, Guo ZS. Oncolytic viruses as therapeutic cancer vaccines. Mol Cancer. 2013;12(1):103.

39. Elankumaran S, Rockemann D, Samal SK. Newcastle disease virus exerts oncolysis by both intrinsic and extrinsic caspase-dependent pathways of cell death. J Virol. 2006;80(15):7522-34.

40. Ahmed I, Ahmad U, Keong Y, Manna N, Othman F. Induction of Nitric Oxide and TNF-A in Newcastle Disease Virus (NDV) AF2240 Infected RAW 264.7 Macrophages and their Cytotoxic Activity on MDA-MB-231 Breast Cancer Cell Line. J Cancer Sci Ther. 2014;6:478-82.

41. Hrabák A, Csuka I, Bajor T, Csatáry LK. The cytotoxic anti-tumor effect of $\mathrm{MTH}-68 / \mathrm{H}$, a live attenuated Newcastle disease virus is mediated by the induction of nitric oxide synthesis in rat peritoneal macrophages in vitro. Cancer Lett. 2006;231(2):279-89.

42. Pecora AL, Rizvi N, Cohen Gl, Meropol NJ, Sterman D, Marshall JL, Goldberg S, Gross P, O'Neil JD, Groene WS, Roberts MS, Rabin H, Bamat MK, Lorence RM. Phase I trial of intravenous administration of PV701, an oncolytic virus, in patients with advanced solid cancers. J Clin Oncol. 2002;20(9):2251-66.

43. Freeman Al, Zakay-Rones Z, Gomori JM, Linetsky E, Rasooly L, Greenbaum E, Rozenman-Yair S, Panet A, Libson E, Irving CS, Galun E, Siegal T. Phase I/II trial of intravenous NDV-HUJ oncolytic virus in recurrent glioblastoma multiforme. Mol Ther. 2006;13(1):221-8.

44. Phuangsab A, Lorence RM, Reichard KW, Peeples ME, Walter RJ. Newcastle disease virus therapy of human tumor xenografts: antitumor effects of local or systemic administration. Cancer Lett. 2001;172(1):27-36.

45. Zulkifli MM, Ibrahim R, Ali AM, Aini I, Jaafar H, Hilda SS, Alitheen NB, Abdullah JM. Newcastle diseases virus strain V4UPM displayed oncolytic ability against experimental human malignant glioma. Neurol Res. 2009;31(1):3-10.

46. Alabsi AM, Bakar SAA, Ali R, Omar AR, Bejo MH, Ideris A, Ali AM. Effects of newcastle disease virus strains AF2240 and V4-UPM on cytolysis and apoptosis of leukemia cell lines. Int J Mol Sci. 2011;12(2011):8645-60.

47. Ahmad U, Ahmed I, Keong YY, Abd Manan N, Othman F. Inhibitory and apoptosis-inducing effects of newcastle disease virus strain AF2240 on mammary carcinoma cell line. Biomed Res Int. 2015;2015.

48. Harvie M, Howell A, Vierkant RA, Kumar N, Cerhan JR, Kelemen LE, Folsom $A R$, Sellers TA. Association of gain and loss of weight before and after menopause with risk of postmenopausal breast cancer in the lowa women's health study. Cancer Epidemiol Biomark Prev. 2005;14(3):656-61.

49. Chlebowski RT, Aiello E, McTiernan A. Weight loss in breast cancer patient management. J Clin Oncol. 2002;20(4):1128-43.

50. Gowda S, Desai PB, Hull W, Math AA, Vernekar SN, Kulkarni SS. A review on laboratory liver function tests. Pan Afr Med J. 2009:3:17.

51. Rahman MF, Siddiqui MK, Jamil K. Effects of Vepacide (Azadirachta indica) on aspartate and alanine aminotransferase profiles in a subchronic study with rats. Hum Exp Toxicol. 2001;20(5):243-9.

52. Parvez S, Tabassum H, Rehman H, Banerjee BD, Athar M, Raisuddin S. Catechin prevents tamoxifen-induced oxidative stress and biochemical perturbations in mice. Toxicology. 2006;225(2-3):109-18.

53. Elefsiniotis ISPK, Ilias A, Pallis L, Mariolis A, Glynou I, Kada H, Moulakakis A. Tamoxifen induced hepatotoxicity in breast cancer patients with preexisting liver steatosis: the role of glucose intolerance. Eur J Gastroenterol Hepatol. 2004;16(6):593-8. 
54. Nyblom H, Björnsson E, Simrén M, Aldenborg F, Almer S, Olsson R. The AST/ ALT ratio as an indicator of cirrhosis in patients with PBC. Liver Int. 2006; 26(7):840-5

55. Huang SS, Huang PH, Leu HB, Wu TC, Lin SJ, Chen JW. Serum bilirubin predicts long-term clinical outcomes in patients with cardiac syndrome $\mathrm{X}$. Heart. 2010;96(15):1227-32

56. Rios DL, Cerqueira CC, Bonfim-Silva R, Araújo LJ, Pereira JF, Gadelha SR, Barbosa AA. Interleukin-1 beta and interleukin-6 gene polymorphism associations with angiographically assessed coronary artery disease in Brazilians. Cytokine. 2010;50(3):292-6.

57. Mitsuyama K, Sata M, Rose-John S. Interleukin-6 trans-signaling in inflammatory bowel disease. Cytokine Growth Factor Rev. 2006;17(6):451-61.

58. Zhang Y, Hayes A, Pritchard A, Thaker U, Haque MS, Lemmon H, Harris J, Cumming A, Lambert JC, Chartier-Harlin MC, St Clair D, Iwatsubo T, Mann DM, Lendon CL. Interleukin-6 promoter polymorphism: risk and pathology of Alzheimer's disease. Neurosci Lett. 2004;362(2):99-102.

59. Esfandi F, Ghobadloo SM, Basati G. Interleukin-6 level in patients with colorectal cancer. Cancer Lett. 2006;244(1):76-8.

60. Dowlati A, Levitan N, Remick SC. Evaluation of interleukin-6 in bronchoalveolar lavage fluid and serum of patients with lung cancer. J Lab Clin Med. 1999;134(4):405-9.

61. Soygur H, Palaoglu O, Akarsu ES, Cankurtaran ES, Ozalp E, Turhan L, Ayhan IH. Interleukin-6 levels and HPA axis activation in breast cancer patients with major depressive disorder. Prog Neuro-Psychopharmacol Biol Psychiatry. 2007;31(6):1242-7.

62. Hodge DR, Xiao W, Wang LH, Li D, Farrar WL. Activating mutations in STAT3 and STAT5 differentially affect cellular proliferation and apoptotic resistance in multiple myeloma cells. Cancer Biol Ther. 2004;3(2):188-94.

63. Hideshima T, Nakamura N, Chauhan D, Anderson KC. Biologic sequelae of interleukin-6 induced PI3-K/Akt signaling in multiple myeloma. Oncogene. 2001;20(42):5991-6000.

64. Lorence RM, Rood PA, Kelley KW. Newcastle Disease Virus as an Antineoplastic Agent: Induction of Tumor Necrosis Factor-a and Augmentation of Its Cytotoxicity. J Natl Cancer Inst. 1988;80(16):1305-12.

65. Rood PA, Lorence RM, Kelley KW. Serum Protease Inhibitor Abrogation of Newcastle Disease Virus Enhancement of Cytolysis by Recombinant Tumor Necrosis Factors Alpha and Beta. J Natl Cancer Inst. 1990;82(3):213-7.

66. Washburn B, Weigand MA, Grosse-Wilde A, Janke M, Stahl H, Rieser E, Sprick MR, Schirrmacher V, Walczak H. TNF-related apoptosis-inducing ligand mediates tumoricidal activity of human monocytes stimulated by Newcastle disease virus. J Immunol. 2003;170(4):1814-21.

67. Eggermont AM, de Wilt JH, ten Hagen TL. Current uses of isolated limb perfusion in the clinic and a model system for new strategies. Lancet Oncol. 2003:4(7):429-37.

68. Sgadari C, Angiolillo AL, Tosato G. Inhibition of angiogenesis by interleukin12 is mediated by the interferon-inducible protein 10. Blood. 1996:87(9): 3877-82.

69. Dias S, Thomas H, Balkwill F. Multiple molecular and cellular changes associated with tumour stasis and regression during $\mathrm{IL}-12$ therapy of a murine breast cancer model. Int J Cancer. 1998;75(1):151-7.

70. HD NCLE, McKinney TG, Tahara H, Nalesnik MA, Brunda MJ, Gately MK, Wolf SF, Schreiber RD, Storkus WJ. Recombinant IL-12 administration induces tumor regression in association with IFN-gamma production. J Immunol. 1994;153(4):1697-706.

71. Elgert KD. Immunology: Understanding the immune system. 2nd ed. New Jersey: Wiley; 2009.

72. Yue FY, Dummer R, Geertsen R, Hofbauer G, Laine E, Manolio S, Burg G. Interleukin-10 is a growth factor for human melanoma cells and downregulates HLA class-I, HLA class-II and ICAM-1 molecules. Int J Cancer. 1997; 71(4):630-7.

73. Piancatelli D, Romano P, Sebastiani P, Adorno D, Casciani CU. Local expression of cytokines in human colorectal carcinoma: evidence of specific interleukin-6 gene expression. J Immunother. 1999;22(1):25-32.

74. Moore KW, de Waal Malefyt R, Coffman RL, O'Garra A. Interleukin-10 and the interleukin-10 receptor. Annu Rev Immunol. 2001;19:683-765.

75. Hatanaka H, Abe Y, Naruke M, Tokunaga T, Oshika Y, Kawakami T, Osada H, Nagata J, Kamochi J, Tsuchida T, Kijima H, Yamazaki H, Inoue H, Ueyama Y, Nakamura M. Significant correlation between interleukin 10 expression and vascularization through angiopoietin/TIE2 networks in non-small cell lung cancer. Clin Cancer Res. 2001;7(5):1287-92.
76. Gerger A, Renner W, Langsenlehner T, Hofmann G, Knechtel G, Szkandera J, Samonigg $\mathrm{H}$, Krippl $\mathrm{P}$, Langsenlehner U. Association of interleukin-10 gene variation with breast cancer prognosis. Breast Cancer Res Treat. 2010;119(3): 701-5.

77. Kozłowski L, Zakrzewska I, Tokajuk P, Wojtukiewicz MZ. Concentration of interleukin-6 (IL-6), interleukin-8 (IL-8) and interleukin-10 (IL-10) in blood serum of breast cancer patients. Rocz Akad Med Bialymst. 2003;48:82-4.

78. Razmkhah M, Jaberipour M, Erfani N, Habibagahi M, Talei AR, Ghaderi A. Adipose derived stem cells (ASCs) isolated from breast cancer tissue express IL-4, IL-10 and TGF- $\beta 1$ and upregulate expression of regulatory molecules on T cells: do they protect breast cancer cells from the immune response? Cell Immunol. 2011;266(2):116-22.

79. Toi M, Harris AL, Bicknell R. Interleukin-4 is a potent mitogen for capillary endothelium. Biochem Biophys Res Commun. 1991;174(3):1287-93.

80. Ueno $T$, Toi M, Saji H, Muta M, Bando H, Kuroi K, Koike M, Inadera H, Matsushima K. Significance of macrophage chemoattractant protein-1 in macrophage recruitment, angiogenesis, and survival in human breast cancer. Clin Cancer Res. 2000;6(8):3282-9.

81. Lebrecht A, Grimm C, Lantzsch T, Ludwig E, Hefler L, Ulbrich E, Koelbl H. Monocyte chemoattractant protein-1 serum levels in patients with breast cancer. Tumour Biol. 2004;25(1-2):14-7.

82. Conti P, DiGioacchino M. MCP-1 and RANTES are mediators of acute and chronic inflammation. Allergy Asthma Proc. t2001;22(3):133-7.

\section{Ready to submit your research? Choose BMC and benefit from:}

- fast, convenient online submission

- thorough peer review by experienced researchers in your field

- rapid publication on acceptance

- support for research data, including large and complex data types

- gold Open Access which fosters wider collaboration and increased citations

- maximum visibility for your research: over $100 \mathrm{M}$ website views per year

At BMC, research is always in progress.

Learn more biomedcentral.com/submissions 